\title{
Isolation and characterization of the tissue and development-specific potato snakin-1 promoter inducible by temperature and wounding
}

\author{
Natalia I. Almasia ${ }^{1}$ Vanesa Narhirñak $^{1} \cdot$ H. Esteban Hopp ${ }^{1} \cdot$ Cecilia Vazquez-Rovere $^{1} \square$ \\ 1 Instituto de Biotecnología, Centro Nacional de Investigaciones Agropecuarias, Instituto Nacional de \\ Tecnología Agropecuaria, Castelar, Los Reseros y Dr. N. Repetto, Hurlingham, Provincia de Buenos Aires, \\ Argentina \\ $\triangle$ Corresponding author: cvazquez@cnia.inta.gov.ar \\ Received April 26, 2010 / Accepted June 25, 2010 \\ Published online: September 15, 2010 \\ (c) 2010 by Pontificia Universidad Católica de Valparaíso, Chile
}

\begin{abstract}
Snakin-1 (StSN1) is a broad-spectrum antimicrobial peptide isolated from Solanum tuberosum. Homologous proteins have been identified in a wide range of species but there is no apparent consensus in the roles they play. A 1394 bp fragment of the 5'upstream region of StSN1 gene, designated PStSN1, was isolated from the potato genome and sequenced. Bioinformatics analyses revealed a total of 55 potential regulatory motifs related to tissue-specificity, stress, defence and hormone responsiveness, among others. PStSN1 spatial and temporal activity was studied in transgenic Arabidopsis plants expressing a reporter gene under this promoter control (PStSN1::GUS). Histochemical staining revealed PStSN1::GUS expression in the root vasculature, cotyledons, young leaves and floral organs. Moreover, GUS staining was detected in young developmental stages gradually decreasing as the plant aged. Stress treatments on transgenic plants showed that PStSN1 activity was induced by high/low temperature and wounding. The characterization of PStSN1 in a model plant establishes a framework for the understanding of its possible biological functions and provides a potential tool for plant modification through genetic engineering.
\end{abstract}

Keywords: antimicrobial peptide, inducible promoter, potato, snakin/GASA

\section{INTRODUCTION}

Snakin-1 (StSN1) is an antimicrobial cysteine- rich peptide isolated from Solanum tuberosum that is active against a wide range of pathogens in vitro (Segura et al. 1999; Berrocal-Lobo et al. 2002). Recently, we demonstrated that overexpression of StSN1 gene in potato transgenic plants enhances resistance against two economically important potato pathogens, Rhizoctonia solani and Erwinia carotovora, showing that StSN1 has also in vivo antifungal and antibacterial activity (Almasia et al. 2008). StSN1 expression was detected in potato tubers, stems, axillary buds and young floral buds by RNA gel blot hybridization and it was suggested that StSN1 
could be a component of constitutive defence barriers, especially in storage and reproductive plant organs (Segura et al. 1999). Since StSN1 amino acid sequence alignments show similarity with members of the tomato GAST family (gibberellic acid stimulated transcript) and Arabidopsis GASA family (gibberellic acid stimulated in Arabidopsis) it was classified as a member of snakin/GASA family (Berrocal-Lobo et al. 2002). Homologous genes have been also identified and characterized in a wide range of species within monocotyledonous and dicotyledonous plants (Shi et al. 1992; Ben-Nissan and Weiss, 1996; Kotilainen et al. 1999; Furukawa et al. 2006) but there is no apparent consensus regarding their biological roles. Members of this family were

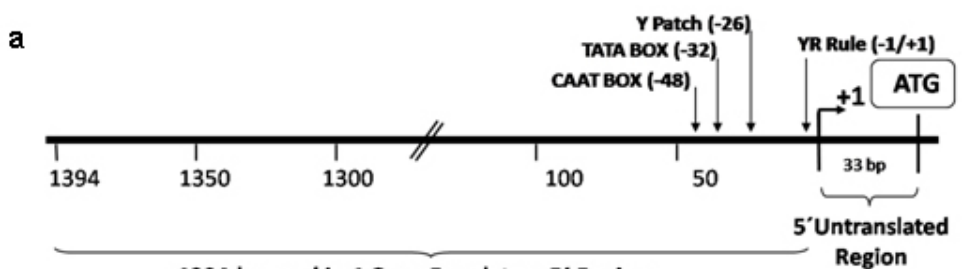

1394-bp snakin-1 Gene Regulatory 5 ' Region

b 1394 GTCGACGTCAGTGTTCGGAGCTGATTGAGCACTGCAGGAAATCTCTATTTCTGGGGGGGatG 1331 ACGGCTCTCCAAACAAATITTTTTTCTCCATATCCAAAACTCGATTTTGAGACATTTGATTAAG 1268 AATGGTCCATGCACCACAATTCATGTTGATAAAGTTATGATACATATAAAAGATCAATTTAAAG 1205 AGATTTCAAATGAATTTACAATTTTGTAGCCACTCAATTATTATTGTACGACTTTGGGTTGAA 1142 TGCTCAAGTGGACTGAAATTTGGATAAATATCTTGATAAAATTAACAAAAGAGAATACTTGAA 1079 AGTTAAAAATTGAAAAAAATAATCTAGAAAGAATAATTCGAACTTCCAAATTTGACATCGATC 1016 GTACAAATTTGTGAAGAAAACTTAGCGGTTTCGGTACAACACTTTACACAGAAGTGGAGACTT 953 GGAGTGAAGTTAGGTAAAAATATTGCTTAATTTTTTCATAGAGAACTTTAGGAATTATATTTA 890 TTACTATAATTTATGTCATGTCACCTCACCAAAACAGTTCCATATTTCTTTTCTTTGGATAAA 827 AGGAAAAAAATTTGTCTAATACGTATTAAAAATCAATCAAAATCTTAATGATCTATGTAGCCA -764 TAAAATTATTTACTTAATTATAAAATTGATGTTTGGCTATAAAAATTCAAACTAAATTTGAAA -701 AACCATTTGAAACTGTTTTCCAACTCATTTTAACTTTTGAATATATTCATACTCAAATACAAA 638 AAATATAATTAAATAAAATTTTCCGTTCAACTGTAACTTTATAAATTTCAAATAACAATAATA 575 ACTACAAATAAAGTTTGAAAAGAATAAATATAAGCTTATCTTACTCGTAAAAGCCTATTTTTAC
ENDOSPERM EXPESSION 512 GAAAGATAGAAAAATGTAACTCTATACTTTCAAATATAAAACAAAAATATTTAAAAATTTATG

449 ACGAAACGTCTGCTTAATAGCCAGCTGCACAAATGCCAAGCATAGTACAAAAACAGAAGATGA 386 ENDOSPERM EXPRESSION 323 TCCGTATTTATTCGCATTCGATATTTATGAAATTTTCATGTTGAATGACTTGTTCATATTTAA

-260 TATTTAAGCCAAAATTATTAATTATCTATATTTAGTGATAGATTAAAATGCGAATATATATAT -197 ATATATTTATTTATTTATTATGATTAACCAACATTATGTATCATGTATTTATTTGAAATGGTA
DEEESE SIRESS RESPONSE
DESPONSE -134 TAAATGAATTTTTTTTACCCTGTTTTGTCAGACCCATCCACAGTTTACTTACTTAATTAGTTAT

-71 AAAAAACATTTATAGTGGACCACCAACTTTTCTCCTGGCTATATATTCCCCCATTAAAACCAT 8 TTGGTAATGCTTCACT"TCATCAAATHTTTCAGCTTAGAAAANATG

Fig. 1 StSN1 gene 5'upstream regulatory region. (a) Schematic diagram of the structure of the StSN1 upstream region consisting of the putative promoter plus the ${ }^{\prime}$ ' untranslated region (UTR). The transcription start site (TSS, +1) was predicted at $33 \mathrm{nt}$ from the first base of the translation start site (ATG). Putative cis-elements TATA-box (-32), CAAT-box (-48) a pyrimidine patch ( $\mathrm{Y}$ Patch, $-26 \mathrm{bp}$ ) and a plant dimer motif YR Rule (TG, $-1 /+1)$ were also identified. (b) Nucleotide sequences of cis-acting elements are highlighted as follows: tissue specificity and stress response elements (gray box); 5'UTR (grey font); CAAT-box, TATA-box (underlined) and translation start codon (underlined and bold text). Numbering is defined by the putative TSS. 
implied in very diverse processes including: cell division, cell elongation, transition to flowering, defence and in signaling pathways (Aubert et al. 1998; Kotilainen et al. 1999; Segura et al. 1999; Berrocal-Lobo et al. 2002; Ben-Nissan et al. 2004; De La Fuente et al. 2006; Furukawa et al. 2006; Roxrud et al. 2007). Additionally, although organ specificity and developmental regulation have been described for some of these genes in a few plant species; there is no consensus in their expression patterns either. The promoter of the tomato homologue (RSI-1) was shown to drive $\beta$ glucuronidase (GUS) activity in lateral and adventitious root initials, in the root cap and in vascular tissue (Taylor and Scheuring, 1994). In addition, activity driven by seven out of fifteen identified Arabidopsis GASA promoters has been reported and shown to be restricted to different tissues and developmental stages, suggesting that they fulfil distinct functions in the plant (Aubert et al. 1998; Raventos et al. 2000; Roxrud et al. 2007; Zhang and Wang, 2008; Zhang et al. 2009). In potato, two members of the snakin/GASA peptide family were reported (Segura et al. 1999; Berrocal-Lobo et al. 2002) but their promoter regions remained unstudied. The identification and characterization of promoters contribute to the elucidation of the biological function of the regulated gene. Additionally, organ-specific, developmentally or stress-induced promoters constitute important tools for plant modification through genetic engineering. The use of constitutive and non-specific promoters may be suitable for proof of concept experiments but their use in genetically improved crops presents a number of potential drawbacks (Gittins et al. 2000). The expression of a protein in large amounts or at stages when it is not needed (i.e. in the absence of a biotic stress) taxes on the energy reserves of the cell (Katiyar-Agarwal et al. 1999).

In this context, the isolation and functional analysis of potato StSN1 promoter (PStSN1) denote at the same time fundamental and practical importance. The aim of this work is to provide a useful foundation for the understanding of the physiological role of StSN1 gene by describing the spatial and temporal regulation of its promoter in a model plant. It is also focused on determining the response of PStSN1 upon exposure to biotic and abiotic stress in order to provide a fine description of its modulation. The possible employment of this promoter as a biotechnological tool is also discussed.

\section{MATERIALS AND METHODS}

\section{Biological material and growth conditions}

Solanum tuberosum spp tuberosum cv Kennebec plants were grown in growth chambers (at $22-25^{\circ} \mathrm{C}, 10 \mathrm{hrs}$ dark-14 hrs light), in 4.72 inches in diameter pots. For genomic DNA extraction, 4-week-old plant leaves were harvested. Arabidopsis thaliana plants ecotype Columbia (Col-0, accession CS1092), were raised in growth chambers (at $22^{\circ} \mathrm{C}, 8 \mathrm{hrs}$ dark-16 hrs light). Pseudomonas syringae pv tomato DC3000 strain were maintained as described by De Torres et al. 2003 and De Torres et al. 2006.

\section{Isolation of upstream promoter sequence}

Potato genomic DNA was isolated from leaves using the Nucleon ${ }^{\mathrm{TM}}$ PhytoPure ${ }^{\mathrm{TM}}$ Genomic DNA Extraction Kit (Amersham, UK) and Inverse Polymerase 
Chain Reaction (IPCR) technique was performed according to Ochman et al. (1988). The DNA template was EcoRI-digested, diluted to obtain $0.6 ; 6$ or $24 \mathrm{ng} / \mu \mathrm{l}$ concentrations and ligated (T4 ligase, Epicentre Technologies, USA). PCR was performed using primers that were based on potato SN1 sequence (AF014396) (SN1/77: CCAGCCATGGTAGTTTGAATGAG and SN1/246: ATAGCCACTCCAGGGTGTCC). Nested PCRs, first with primers SN1/65 (GTAGTTTGAATGAGAGAAGG) and SN1/246; and finally with primers SN1/65 and SN1/610 (CAAAGTGCAAGCTGAGATGC) were performed. PCR products were separated by $0.8 \%$ agarose gel electrophoresis and a fragment of approximately 1000 bp was amplified from the $0.6 \mathrm{ng} / \mu \mathrm{l}$ original dilution sample. Genome Walker ${ }^{\mathrm{TM}}$ strategy (Clontech, Palo Alto, USA) was used to obtain a larger 5' upstream of the StSN1 gene according to manufacturer's instructions. Briefly, genomic DNA from potato plants was digested with Dral, EcoRV, Pvull and Stul restriction enzimes (NEB). Adaptors were ligated at fragment ends to generate genomic libraries. PCR was performed with primer SN1/+5 (GGGCCATGGGATCCTTCATTTTTTCTAAAGC) and adaptor primer AP1 (GTAATACGACTCACTATAGGGC). A nested PCR was performed with the primer SN1/-477 (CATTTGTGCAAGCTGGCTATTAAGCAGACG) based on the sequence obtained by IPCR and the adaptor primer AP2 (ACTATAGGGCACGCGTGGT). Amplified products were electrophoresed in $0.8 \%$ agarose gel and a 1100 bp fragment was obtained from the Pvull library, cloned into pGEMT (Promega, Madison, USA) and representative resulting clones were sequenced through commercial sequencing facilities (Macrogen Company, Seoul, Korea). To amplify the full-length promoter sequence we used the primer SN1/-1394 (GTCAGTGTTCGGAGCTGATTGAG) deduced from the 5' region obtained by the Genome Walker ${ }^{\mathrm{TM}}$ strategy and the primer $\mathrm{SN} 1 /+0$ (GTCGACTTTTTCTAAAGCTGATAATTTGATG). For PCR assay, $15 \mathrm{ng}$ of genomic DNA were added to a PCR mixture (Taq DNA Polymerase, Invitrogen, USA) according to the following conditions: $94^{\circ} \mathrm{C}$ for $1 \mathrm{~min}, 50^{\circ} \mathrm{C}$ for $1 \mathrm{~min}$, and $72^{\circ} \mathrm{C}$ for 2 min, for 36 cycles. The amplified fragment was cloned in PCRII-TOPO ${ }^{\circledR}$ (TACloning ${ }^{\circledR}$, Invitrogen (EUA), sequenced and analyzed with the BioEdit Sequence Alignment Editor software, Softberry, PlantCARE (Rombauts et al. 1999; Lescot et al. 2002) and Genomatix-MatInspector based on PLACE (Higo et al. 1999) servers. Sequence data from this article have been deposited at the GenBank under accession number GQ421321.

\section{Transformation constructs and plant transformation}

The 1394 bp fragment corresponding to the 5' upstream region of StSN1 gene was cloned into the EcoRI site of the plasmid PAKK 1431. The resulting recombinant intermediate plasmid was digested with Pstl and the insert was subcloned into the Pstl site of the binary vector pCambia2300 (CAMBIA, Canberra, Australia) giving rise to PStSN1::GUS. Standard molecular biology procedures were carried out as described by Sambrook et al. (1989). Equivalent constructs without promoter (EV::GUS) or with Cauliflower mosaic virus $35 \mathrm{~S}$ promoter (35S::GUS) were used as negative and positive controls, respectively. Constructs were electroporated into GV3101 Agrobacterium tumefaciens strain. Arabidopsis thaliana was transformed by using the floral dip method (Clough and Bent, 1998). Transformed plants were selected in Petri dishes with agar Murashige and Skoog medium containing $50 \mathrm{mg} \mathrm{ml}^{-1}$ kanamycin, then transferred to soil for growth under normal conditions (as described above), selfed and finally homozygous T3 lines were selected and collected. 
Temperature and wounding inducible potato promoter

Table 1. Transcription factors binding sequences on SN1 promoter according to PlantCare program. Selected Matrix score for all elements $>=5$.

\begin{tabular}{|c|c|c|c|c|c|c|}
\hline $\begin{array}{l}\text { Related } \\
\text { Function }\end{array}$ & $\begin{array}{l}\text { Site } \\
\text { Name }\end{array}$ & $\begin{array}{l}\text { Organism } \\
\text { Described }\end{array}$ & sequence & $\begin{array}{l}\text { Matrix } \\
\text { score }\end{array}$ & Position & Strand \\
\hline Auxin & $\begin{array}{l}\text { AuxRR- } \\
\text { core }\end{array}$ & $\begin{array}{l}\text { Nicotiana } \\
\text { tabacum }\end{array}$ & GGTCCAT & 7 & 1265 & + \\
\hline \multirow{2}{*}{$\begin{array}{l}\text { Anaerobic } \\
\text { Induction }\end{array}$} & \multirow[t]{2}{*}{ ARE } & \multirow[t]{2}{*}{ Zea mays } & TGGTTT & 6 & 702 & - \\
\hline & & & TGGTTT & 6 & 15 & - \\
\hline \multirow{4}{*}{$\begin{array}{c}\text { Defense } \\
\text { and Stress }\end{array}$} & \multirow{4}{*}{$\begin{array}{l}\text { TC-rich } \\
\text { repeats }\end{array}$} & \multirow{4}{*}{$\begin{array}{l}\text { Nicotiana } \\
\text { tabacum }\end{array}$} & АТTTTСТССА & 9 & 1312 & + \\
\hline & & & ATTTTCTTCA & 9 & 1005 & - \\
\hline & & & АТTTTСТTCA & 9 & 1069 & - \\
\hline & & & GTTTTCTTAC & 9 & 93 & + \\
\hline Drought & MBS & $\begin{array}{l}\text { Arabidopsis } \\
\text { thaliana }\end{array}$ & CAACTG & 6 & 611 & + \\
\hline \multirow{4}{*}{$\begin{array}{l}\text { Endosperm } \\
\text { Expression }\end{array}$} & \multirow{4}{*}{$\begin{array}{l}\text { Skn- } \\
\text { 1_motif }\end{array}$} & \multirow[t]{4}{*}{ Oryza sativa } & GTCAT & 5 & 876 & + \\
\hline & & & GTCAT & 5 & 390 & - \\
\hline & & & GTCAT & 5 & 452 & - \\
\hline & & & GTCAT & 5 & 279 & - \\
\hline \multirow[t]{2}{*}{ Enhancer } & $\begin{array}{l}\text { 5UTR } \\
\text { Py-rich }\end{array}$ & $\begin{array}{l}\text { Lycopersicon } \\
\text { esculentum }\end{array}$ & ТTТСТTСТСТ & 9 & 846 & + \\
\hline & $\begin{array}{l}\text { TA-rich } \\
\text { region }\end{array}$ & $\begin{array}{l}\text { Nicotiana } \\
\text { tabacum }\end{array}$ & $\begin{array}{c}\text { TATATATATATATATATAT } \\
\text { ATA }\end{array}$ & 20 & 206 & + \\
\hline \multirow[t]{3}{*}{ Ethylene } & \multirow[t]{3}{*}{ ERE } & \multirow{3}{*}{$\begin{array}{c}\text { Dianthus } \\
\text { caryophyllus }\end{array}$} & ATTTCAAA & 8 & 1203 & + \\
\hline & & & ATTTCAAA & 8 & 146 & - \\
\hline & & & ATTTCAAA & 8 & 594 & + \\
\hline Gibberellin & $\begin{array}{l}\text { GARE- } \\
\text { motif }\end{array}$ & $\begin{array}{l}\text { Brassica } \\
\text { oleracea }\end{array}$ & AAACAGA & 7 & 399 & + \\
\hline \multirow[t]{2}{*}{ Heat stress } & \multirow[t]{2}{*}{ HSE } & \multirow{2}{*}{$\begin{array}{l}\text { Brassica } \\
\text { oleracea }\end{array}$} & AAAAAATTTC & 9 & 823 & + \\
\hline & & & AAAAAATTTC & 9 & 129 & - \\
\hline \multirow[t]{20}{*}{ Light } & $\begin{array}{l}\text { AAAC- } \\
\text { motif }\end{array}$ & $\begin{array}{l}\text { Spinacia } \\
\text { oleracea }\end{array}$ & CAATCAAAACCT & 11 & 794 & + \\
\hline & ACE & $\begin{array}{l}\text { Petroselinu } \\
\text { m crispum }\end{array}$ & AAAACGTTTA & 9 & 69 & + \\
\hline & Box 4 & $\begin{array}{l}\text { Petroselinu } \\
\text { m crispum }\end{array}$ & ATTAAT & 6 & 244 & + \\
\hline & \multirow[t]{7}{*}{ Box I } & \multirow{7}{*}{$\begin{array}{l}\text { Pisum } \\
\text { sativum }\end{array}$} & TTTCAAA & 7 & 1202 & + \\
\hline & & & TTTCAAA & 7 & 562 & - \\
\hline & & & TTTCAAA & 7 & 696 & - \\
\hline & & & TTTCAAA & 7 & 146 & - \\
\hline & & & TTTCAAA & 7 & 708 & - \\
\hline & & & TTTCAAA & 7 & 485 & + \\
\hline & & & TTTCAAA & 7 & 593 & + \\
\hline & \multirow{2}{*}{$\begin{array}{l}\text { CATT- } \\
\text { motif }\end{array}$} & \multirow[t]{2}{*}{ Zea mays } & GCATTC & 6 & 1145 & - \\
\hline & & & GCATTC & 6 & 310 & + \\
\hline & $\begin{array}{l}\text { GA- } \\
\text { motif }\end{array}$ & $\begin{array}{l}\text { Arabidopsis } \\
\text { thaliana }\end{array}$ & ATAGATAA & 8 & 239 & - \\
\hline & $\begin{array}{l}\text { GATA- } \\
\text { motif }\end{array}$ & $\begin{array}{l}\text { Arabidopsis } \\
\text { thaliana }\end{array}$ & AAGATAAGATT & 10 & 544 & - \\
\hline & \multirow{2}{*}{$\begin{array}{l}\text { GT1- } \\
\text { motif }\end{array}$} & \multirow[t]{2}{*}{ Avena sativa } & GGTTAAT & 7 & 175 & - \\
\hline & & & GGTTAAT & 6 & 174 & - \\
\hline & I-box & $\begin{array}{l}\text { Flaveria } \\
\text { trinervia }\end{array}$ & CCATATCCAAT & 10 & 1305 & + \\
\hline & $\begin{array}{l}\text { LAMP- } \\
\text { element }\end{array}$ & $\begin{array}{l}\text { Pisum } \\
\text { sativum }\end{array}$ & СТTTATCA & 8 & 1242 & - \\
\hline & \multirow[t]{2}{*}{ Sp1 } & \multirow[t]{2}{*}{ Zea mays } & $\mathrm{CC}(\mathrm{G} / \mathrm{A}) \mathrm{CCC}$ & 5 & 1342 & - \\
\hline & & & $\mathrm{CC}(\mathrm{G} / \mathrm{A}) \mathrm{CCC}$ & 5,5 & 331 & + \\
\hline
\end{tabular}


Almasia et al.

\begin{tabular}{|c|c|c|c|c|c|c|}
\hline & & & $\mathrm{CC}(\mathrm{G} / \mathrm{A}) \mathrm{CCC}$ & 5 & 1341 & - \\
\hline & $\begin{array}{l}\text { TCT- } \\
\text { motif }\end{array}$ & $\begin{array}{c}\text { Arabidopsis } \\
\text { thaliana }\end{array}$ & TCTTAC & 6 & 537 & + \\
\hline & chs- & Daucus & TTACTTAA & 8 & 755 & + \\
\hline & CMA1a & carota & TTACTTAA & 8 & 87 & + \\
\hline $\begin{array}{c}\text { Low- } \\
\text { temperatur } \\
\mathrm{e}\end{array}$ & LTR & $\begin{array}{l}\text { Hordeum } \\
\text { vulgare }\end{array}$ & CCGAAA & 6 & 988 & - \\
\hline Meristem & $\begin{array}{l}\text { CAT- } \\
\text { box }\end{array}$ & $\begin{array}{c}\text { Arabidopsis } \\
\text { thaliana }\end{array}$ & GCCACT & 6 & 1177 & + \\
\hline \multirow[t]{2}{*}{ Metabolism } & O2-site & Zea mays & GATGACATGA & 9 & 875 & - \\
\hline & & & GATGA(C/T)(A/G)TG(A/G) & 8 & -3 & - \\
\hline \multirow[t]{4}{*}{$\begin{array}{c}\text { Methyl } \\
\text { jasmonate }\end{array}$} & $\begin{array}{l}\text { CGTCA- } \\
\text { motif }\end{array}$ & $\begin{array}{l}\text { Hordeum } \\
\text { vulgare }\end{array}$ & CGTCA & 5 & 1333 & - \\
\hline & TGACG & Hordeum & CGTCA & 5 & 451 & - \\
\hline & -motif & vulgare & TGACG & 5 & 1333 & + \\
\hline & & & TGACG & 5 & 451 & + \\
\hline \multirow{2}{*}{$\begin{array}{l}\text { Salicylic } \\
\text { acid }\end{array}$} & \multirow{2}{*}{$\begin{array}{c}\text { TCA- } \\
\text { element }\end{array}$} & \multirow{2}{*}{$\begin{array}{l}\text { Brassica } \\
\text { oleracea }\end{array}$} & GAGAAGAATA & 9 & 1314 & - \\
\hline & & & GAGAAGAATA & 9 & 559 & + \\
\hline $\begin{array}{c}\text { Xylem } \\
\text { expression }\end{array}$ & AC-II & $\begin{array}{c}\text { Phaseolus } \\
\text { vulgaris }\end{array}$ & TCCACCAACCCC & 11 & 341 & + \\
\hline
\end{tabular}

Temperature, mechanical wounding, phytohormone, light/darkness, UV radiation or Pseudomonas syringae treatments

Presence of the transgene in the selected plants was confirmed by PCR using specific primers: SN1/-1394 and AKK (GCAAACACCTGCTGAAACCTTT) for transgenic PStSN1::GUS plants, 35S (ATCTCCACTGACGTAAGGGA) and AKK for transgenic 35S::GUS plants, and GUSUp (GATAGCGCGTGACAAAAACC) and GUSLow (GGGATCCAGGCCTTTGTTTGCCTCCCTGCTG) for all transgenic lines. In addition, we use the primers describe by Hayashi et al. (2003) for PCR amplification of Arabidopsis Actin-2 gene (NM_112764.3) as an internal control (Actin-2Up: AACATTGTGCTCAGTGGTGG and Actin-2Low: TCATCATACTCGGCCTTGG primers). Finally, four independent PStSN1::GUS T3 transgenic lines and two control lines were used for further analysis. At different times samples or whole plants were histochemically stained for GUS visualization by immersing in 5-bromo-4-chloro-3indolyl-beta-D-glucuronic acid, cyclohexylammonium salt solution (X-gluc) (Jefferson et al. 1987) and incubating for $16 \mathrm{hrs}$ at $37^{\circ} \mathrm{C}$. Chlorophyll was then removed from tissues by immersion in $90 \%$ ethanol. Samples were observed and photographed under Nikon SMZ-2T (Japan) magnifying glass or Leica TCS-SP5 Confocal Microscope (Germany) for differential interference contrast (DIC) imaging.

For the different treatments T3 seedlings of transgenic Arabidopsis plants were grown in growth chambers (at $20-25^{\circ} \mathrm{C}, 10 \mathrm{hrs}$ dark-14 hrs light cycle) for 4 to 5 weeks and at least twelve biological replicates were used in each set of assays. For temperature treatment plants, grown at $20^{\circ} \mathrm{C}$ and prior to bolting, were placed at $4{ }^{\circ} \mathrm{C}, 37^{\circ} \mathrm{C}$ or kept at $20^{\circ} \mathrm{C}$ for $4 \mathrm{hrs}$ under darkness. For mechanical wounding treatments, leaves were gently pressed with a pair of sterilized serrated forceps as described Delessert et al. (2005) and collected at 1, 2 or 3 hrs after wounding. Hormone treatments were performed according to Bazzini et al. (2009). Briefly, plants subjected to hormone 
treatment were grown in 1.5 inches individual pots and sprayed with $50 \mathrm{ml}$ of $100 \mu \mathrm{M}$ ABA, $100 \mu \mathrm{M}$ IAA, $50 \mu \mathrm{M}$ GA3 or water (mock-treated) and incubated for 6 hrs under dim light. For light treatment, plants grown under usual dark-light cycle were covered to keep in darkness or left to continue the normal light cycle for $4 \mathrm{hrs}$ prior to sample collection. For UV radiation studies fifty 14 days-old sterilized seedlings, grown in MSG agar medium (Murashige and Skoog media containing $3 \%$ glucose) at $22^{\circ} \mathrm{C}$ under a photoperiod of 16 hrs light-8 hrs dark, were exposed to 100 Watts UV light for 2 min at 24 inches from light bulb in a laminar flow cabinet. Irradiated plants were kept in darkness and collected $2 \mathrm{hrs}$ after treatment. Finally for Pseudomonas syringae infection treatments, the bacterial culture density was adjusted to $\mathrm{OD}_{600} 0.1$ in $10 \mathrm{mM}$ $\mathrm{MgSO}_{4}$ and sprayed on intact leaves of Arabidopsis plants, which were then incubated in a growth chamber at $25^{\circ} \mathrm{C}$ and $80 \%$ relative humidity with a $10 \mathrm{hrs}$ dark$14 \mathrm{hrs}$ light photoperiod according to lacobellis et al. (2003). Negative control plants were inoculated only with $10 \mathrm{mM} \mathrm{MgSO}_{4}$. The dose of bacterial inoculum was empirically adjusted in order to achieve symptoms development within 3 days. Plants were collected at 24 hrs post infection and at $72 \mathrm{hrs}$ when visual scoring of disease symptoms was low (a few water-soaked lesions) and at $72 \mathrm{hrs}$ when scoring was high (several necrotic lesions surrounded by diffuse chlorosis). Plant infection presented a homogeneous distribution in control and transgenic lines.

All samples were stored at $-80^{\circ} \mathrm{C}$ and tested by RT-PCR to check treatments

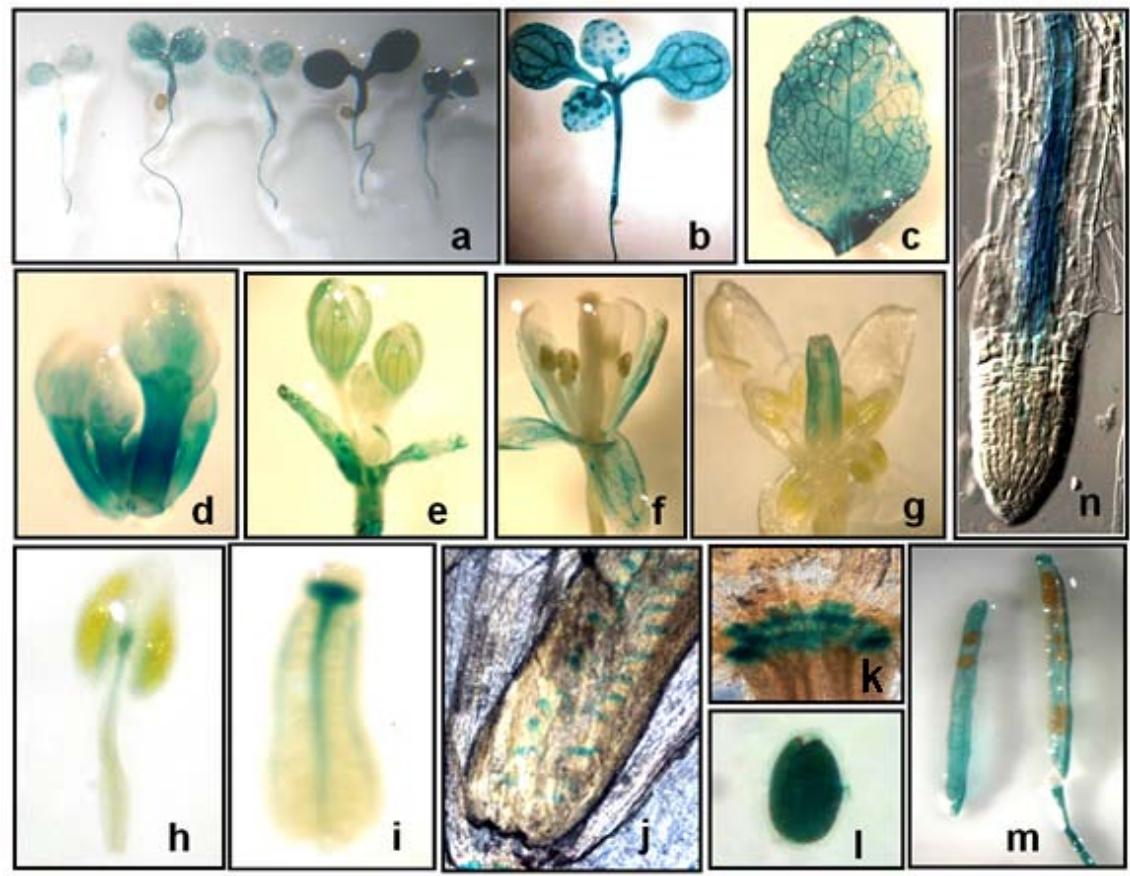

Fig. 2 Histochemical localization of GUS activity in transgenic PStSN1::GUS Arabidopsis plants. Seedlings grown in MSG medium were collected at 4 days (a) or 8 days after seed germination (b); representative young fully expanded leaf of a 20-days-old transgenic plant grown on soil (c); immature floral buds (d); young flower; (e) mature flower (f); old flower (g); stamen (h); stigma (i); ovary (j); base flower (k); matured siliques with untreated seeds $(\mathrm{m})$; mechanically wounded stained seeds (I) and root (n). (j), (k) and (n) are differential interference contrast (DIC) images. 
effectiveness. Afterwards, four plants of each line and each treatment were histochemically stained as described above while at least eight plants of each line were immediately frozen in liquid nitrogen and stored until RNA isolation and quantitative analysis of GUS activity were performed. To this last aim, fluorometric measurements of GUS activity were carried out according to Jefferson et al. (1987) using 4-methyl umbelliferyl glucuronide (MUG, $\beta$-D-glucoronide hydrate, Fluka, BioChemika, Switzerland) as substrate and employing a fluorescence spectrophotometer SpectraMax ${ }^{\circledR}$ GEMINI EM (Molecular Devices Corporation, Sunnyvale, CA, USA). Protein concentrations were determined according to Bradford (1976) and the GUS enzyme activity was expressed as nmol of 4-methylumbelliferone $(\mathrm{MU})$ produced per mg protein per min. Statistical analyses of relative GUS activity were performed by pair comparisons (between treated plants of each line versus mock-treated plants of the same line) according to Mann-Whitney tests employing the InfoStat software (InfoStat version 2008, Grupo InfoStat, FCA, Universidad Nacional de Córdoba, Argentina). For each line data were normalized to the average percentage of mocked-treated plants which were considered as $100 \%$.

\section{RT-PCR transcript analysis}

RNA extraction was carried out by using RNeasy plant mini kit (QiaGen, $\mathrm{GmbH}$, Hilden, Germany) and cDNAs were synthesized by using Superscript III (Invitrogen, Carlsbad, CA, USA) with random primers according to manufacturer's instructions. In order to test for the treatment effectiveness, control genes were amplified by RT-PCR. These genes were: ABA-inducible RD22 gene (NM_122472) (Yamaguchi-Shinozaki and Shinozaki, 1993b) (RD22Up: GTGGCTAAGAAGAACGCACCGATGC and RD22Low: CTCTAATTTTATTATAGGTTTTTGCAAAAC primers were used); IAAinducible SAUR-AC1 gene (S70188) (Gil et al. 1994) (SAUR-AC1Up: TTGAGGAGTTTCTTGGGTGC and SAUR-AC1Low: CATGGTATTGTTAAGCCGCC), GA3-inducible APT1 (NM_179383) (Moffatt et al. 1994) (APT1Up: TCCCAGAATCGCTAAGATTGCC and APT1Low: CCTTTCCCTTAAGCTCTG), low temperature-inducible RD-29A (D13044) (Yamaguchi-Shinozaki and Shinozaki,

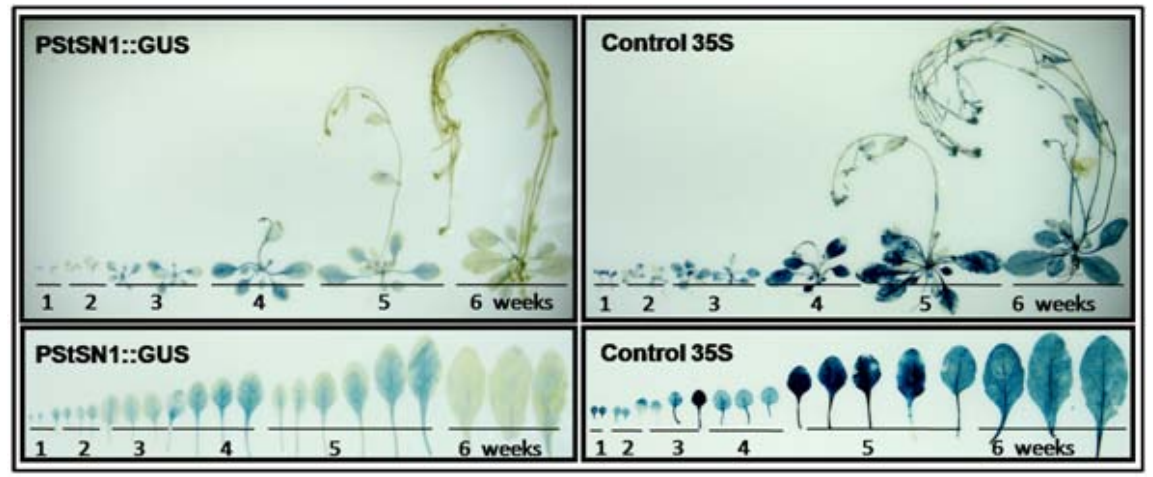

Fig. 3 Temporal expression patterns of PStSN1::GUS in Arabidopsis. Plants were collected at $1,2,3,4,5$ and 6 weeks after emerging from seeds for histochemical localization of GUS activity in sequential developmental stages. Staining representative plants of transgenic harboring PStSN1::GUS construct is presented and one 35S::GUS control line (called Control 35S). After staining some leaves were detached to analyze in detail the gradual decrease in promoter activity as plants aged. 
1993a; Charng et al. 2007) (RD29AUp: GAATGGTGCGACTAAGATGTTTAGGAA and RD29ALow: GTACAGATTCAGTGGGTTTGGTGTAAT), high temperatureinducible HSP21 (EU289266) (Osteryoung et al. 1993) (HSPUp: ATGGCTTCTACACTCTCATTTGCTG and HSPLow: CTACTGAATCTGGACATCGATGACT), light-inducible CHS (Feinbaum and Ausubel, 1988) (NM_121396) (CHSUp: TGCCATAGACGGACATTTGA and CHSLow: TGTCGCCCTCATCTTCTCTT) and wound-inducible Ap2 (BT008480) (Riechmann et al. 2000) (Ap2Up: CAGTAGAGAGATGGAGATGTCTGC and Ap2Low: TGTTACTCGAAGCTTCTCTCACT). Internal control Actin-2 gene was also amplified as mentioned above. In all cases, PCR conditions were: $94^{\circ} \mathrm{C}$ for $1 \mathrm{~min}, 50^{\circ} \mathrm{C}$ for 1 $\min$, and $72^{\circ} \mathrm{C}$ for $1 \mathrm{~min}$, for 25 cycles.

\section{RESULTS}

\section{Cloning and sequence analysis of the PStSN1 region}

To explore the upstream regulatory region of potato StSN1 antimicrobial gene, a 1394 bp DNA fragment, designated PStSN1, was amplified from genomic DNA by combining IPCR and Genome Walker ${ }^{\mathrm{TM}}$ strategies as described in Materials and Methods section. A putative transcription start site (TSS) was identified in silico located $33 \mathrm{bp}$ upstream of the first base of the translation start site, satisfying the YR Rule (Yamamoto et al. 2007) and agreeing with previous information regarding the 5' region sequence (Segura et al. 1999). Putative cis-elements TATA-box (-32 bp) and CAAT-box (-48 bp) were also predicted as well as a pyrimidine patch (Y Patch) at -26 bp (Figure 1a). A more detailed bioinformatic search for promoter motifs present in PStSN1 was carried out to define putative cis-acting elements using PLACE and PlantCARE databases (Higo et al. 1999; Rombauts et al. 1999; Lescot et al. 2002). A total of 55 potential regulatory motifs, corresponding to known not common cis-acting element of eukaryotic promoters, were identified considering elements which matrix score $>=5$ (Table 1). For further studies predicted elements related to tissue specificity (endosperm, xylem and meristem expression), abiotic stress (heat and low temperature), gibberellin, auxin, defense and light were considered. Fragment sequences confirmed by experiments in this work were indicated in Figure 1b. The remaining elements were related to drought-induction, seed storage metabolism, anaerobic induction, salicylic acid, ethylene or methyl jasmonate-response. In order to study this 5' upstream region of StSN1 gene, a chimeric unit consisting of the GUS reporter gene under the PStSN1 control (PStSN1::GUS) was obtained. Transient expression assays by agroinfiltration of Nicotiana benthamiana leaves confirmed that the cloned region correspond to the PStSN1 promoter (data not shown). Since Arabidopsis thaliana has many advantages as a model system for gene functional studies, such as a short life cycle, small size and well developed study techniques we obtain Arabidopsis transgenic lines expressing PStSN1::GUS for stable expression studies.

\section{Spatial and temporal expression patterns of PStSN1::GUS in Arabidopsis}

To precisely define the spatial expression pattern of PStSN1, GUS expression was monitored by histochemical staining of PStSN1::GUS Arabidopsis homozygous transgenic lines. Although variable GUS staining intensities were registered in different transgenic lines in 4-days-old seedlings; conspicuous GUS expression was detected in cotyledons, hypocotyls and radicles, as shown in Figure 2a. In a typical 
intermediate-intensity staining line, at 8-days-old seedlings, strong GUS expression was detected in a netted venation pattern in cotyledons and in a dot-like pattern in the first two true leaves (Figure 2b). Also netted venation GUS activity was detectable in young but fully expanded leaves (Figure 2c). Strong GUS staining appeared in immature floral buds (Figure 2d) and in sepals of young and mature flowers (Figure $2 \mathrm{e}$ and $2 \mathrm{f}$ respectively), while in old flowers staining was mainly located in the style (Figure $2 \mathrm{~g}$ ). In addition, GUS activity was detectable in the top of the filament of the stamen, on the connective (Figure $2 \mathrm{~h}$ ) and in the vascular tissues of the stigma (Figure 2i). Differential interference contrast images showed GUS staining in the ovules within the ovary (Figure 2j) and in the abscission zone of the flower base (Figure 2k). In mature siliques GUS staining appeared in valves but not in seeds (Figure 2h), however, strong GUS signal was detected in seeds when they were mechanically wounded to facilitate glucuronic acid solution penetration (Figure 2I). Finally, GUS expression was restricted to the vascular cylinder in roots, weakly in meristematic zone, strongly in elongation zone and decreasing in intensity towards the maturation zone (defined according to Brady et al. 2007) (Figure 2n). These results indicate that. PStSN1::GUS exhibits a specific regulated gene expression in vasculature, vegetative and reproductive tissues.

In order to examine the temporal expression patterns of PStSN1::GUS, whole plants at sequential developmental stages were histochemically stained. Strong GUS staining was detected in young stages gradually decreasing as the plant aged (from the first to the sixth week, covering stages 1 to 9 according to Boyes et al. 2001). A remarkable reduction in stain intensity was registered when the plant senesced at the sixth week (Figure 3, left panels). It is interesting to note that GUS activity decreased in leaf vascular tissues towards late developmental stages (Figure 3, lower panels). As expected, Arabidopsis transgenic lines harboring 35S::GUS presented a ubiquitous and constitutive temporal expression (Figure 3, right panels) while no GUS staining was registered for EV::GUS control lines (harbouring a construction without promoter) (data not shown). The above results indicate that PStSN1 modulates gene expression in a development-specific manner in transgenic Arabidopsis plants.

\section{PStSN1 is induced by temperature shock}

Since PStSN1 exhibited predicted elements related to heat stress and low temperature, GUS activity was assessed on four transgenic PStSN1::GUS Arabidopsis lines after temperature shocks. Based on their relative level of GUS expression, one high expressing line (Line $8 \mathrm{~B}$ ), two intermediate (Lines $2 \mathrm{~B}$ and $5 \mathrm{C}$ ) and one weak expressing line (Line $11 \mathrm{~A}$ ) were selected. Plants were grown at $20^{\circ} \mathrm{C}$ and subsequently shocked (at $4^{\circ} \mathrm{C}$ or $37^{\circ} \mathrm{C}$ ) or kept at $20^{\circ} \mathrm{C}$ for 4 hrs under darkness. Quantitative GUS activity assay clearly indicated that reporter protein activity was strongly induced upon exposure to either high or low temperature shock in PStSN1::GUS transgenic lines, while the Arabidopsis line harbouring the constitutive promoter 35S CaMV did not present significant changes in GUS activity between treated and untreated plants (Figure 4a). Histochemical GUS staining also was stronger at $4^{\circ} \mathrm{C}$ or $37^{\circ} \mathrm{C}$ compare to plants kept at $20^{\circ} \mathrm{C}$ (Figure $4 \mathrm{~b}$ ). Treatments effectiveness was confirmed through RT-PCR of RD-29 gene and HSP21 gene which are known to be induced by low and high temperature respectively (Figure 4c). These results demonstrate that PStSN1 is induced by temperature shock suggesting that the cis-acting temperature responsive elements detected in silico are likely to be functional. 
$\mathbf{a}$

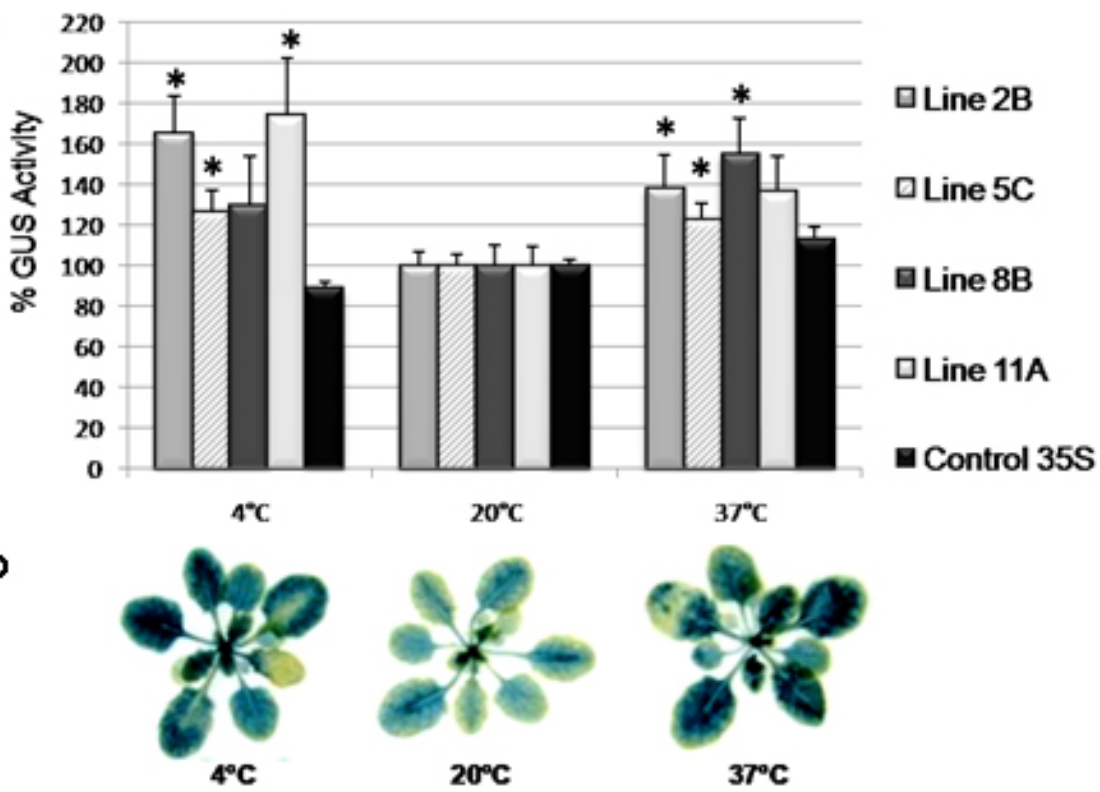

C

RD-29A

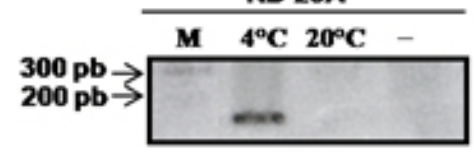

Actin-2

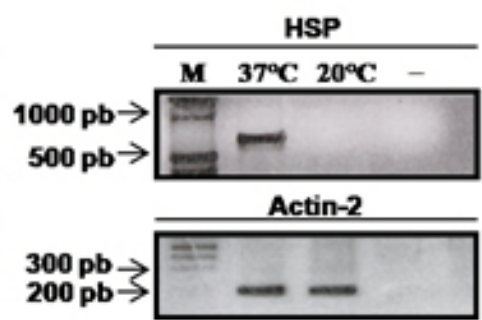

Fig. 4 Temperature induction of PStSN1 activity in transgenic Arabidopsis lines. For temperature induction assays, Arabidopsis plants grown under $20^{\circ} \mathrm{C}$ were changed to $4^{\circ} \mathrm{C}$ or $37^{\circ} \mathrm{C}$ or kept at $20^{\circ} \mathrm{C}$ for 4 hrs under darkness. Four independent transgenic Arabidopsis lines harboring PStSN1::GUS constructs (Lines $2 \mathrm{~B}, 5 \mathrm{C}, 8 \mathrm{~B}$ and $11 \mathrm{~A}$ ) and one $35 \mathrm{~S}:: \mathrm{GUS}$ control line were evaluated. Whole plants were harvested for GUS assays.(a) GUS activity was measured as nmoles of MU (methylumbelliferone) produced per min per $\mu \mathrm{g}$ of protein and the data measured at $4^{\circ} \mathrm{C}$ and at $37^{\circ} \mathrm{C}$ were relatively expressed to the $20^{\circ} \mathrm{C}$ set of data. Bar graphs represent the average percentage of GUS activity $\pm \mathrm{SE}$ measured in ten biological replicates. (b) Histochemical localization of GUS activity in plants of Line 2B after temperature induction treatments. (c) Assessment of the temperature treatment effectiveness by RT-PCR of genes induced by low (RD-29A) or high (HSP21) temperature (upper panels). Specific Actin-2 transcript amplification was detected in all plants as an internal control for CDNA synthesis (lower panels). M: Molecular Marker $1 \mathrm{~Kb}$; (-) Negative PCR control (without DNA). * denote significant differences $(P<0.05)$.

\section{PStSN1 is induced by wounding}

In order to examine the effect of mechanical wounding on PStSN1, leaves were gently pressed with a pair of serrated forceps and stained after 1, 2 or $3 \mathrm{hrs}$. GUS staining was stronger in wounded transgenic PStSN1::GUS leaves compared to unwounded leaves from the same line. Induction seems to be very fast and durable since no 
considerable differences were detected in leaves stained at different times after wounding (Figure 5a). As expected, non-staining changes were displayed after treatments in control lines (35S::GUS and EV::GUS) (data not shown). Wound induction was confirmed by quantitative GUS activity assays in all selected transgenic lines $2 \mathrm{hrs}$ after wounding (Figure 5b). Significant differences were registered in the four lines; while 35S::GUS line did not present significant changes in GUS activity after treatment. Plants were tested by RT-PCR to check treatment effectiveness by amplifying the control Ap2 gene which is known to be induced by wounding (Figure 5c). These results demonstrate that PStSN1 is induced by wounding in transgenic Arabidopsis plants.

PStSN1 activity is unaltered by phytohormones, light/darkness, UV radiation treatments or by Pseudomonas syringae infection

It was reported that StSN1 gene did not respond to abiotic or biotic stimuli in young potato leaves (Segura et al. 1999) however it has been shown that SN1 homologues genes are regulated by phytohormones in other plant species (Shi et al. 1992; Taylor and Scheuring, 1994; Ben-Nissan and Weiss, 1996; Aubert et al. 1998; Kotilainen et al. 1999; Ben-Nissan et al. 2004; Zhang and Wang, 2008). Additionally, potential regulatory motifs related to hormones were identified in PStSN1. Therefore to study if PStSN1 can be regulated by phytohormones in Arabidopsis analyses of GUS activity was performed on transgenic lines after different hormone treatments. Plants from the PStSN1::GUS selected lines and control ones were sprayed with abscisic acid (ABA), indol acetic acid (IAA), gibberellic acid (GA) or water (mock treatment). Figure 6a shows that no significant differences in GUS activities were observed in the different PStSN1::GUS or 35S::GUS expressing lines treated with any of the assayed phytohormones when compared to their respective mock treated plants. Subsequently, as potential light regulatory motifs were also identified in PStSN1 the effect of light in GUS expression was examined on the transgenic lines. Plants grown under 14 hrs light-10 hrs dark cycle were covered at the end of the dark cycle to keep in darkness or left to continue the normal light cycle for $4 \mathrm{hrs}$ prior to collection. Lines containing the PStSN1::GUS construct and control line harbouring 35S::GUS showed no statistically significant differences in GUS activities under darkness compared to control plants kept in light (Figure 6b). Hormone and light/darkness treated plants were tested by RT-PCR to check treatments effectiveness (Figure 6e).

Since rice OsGASR1 (a StSN1 homologue) was shown to be a UV-responsive gene (Furukawa et al. 2006), UV radiation treatment was also investigated on two independent PStSN1::GUS lines. To this aim, seedlings were exposed to UV radiation and collected 2 hrs later to determine GUS activity. PStSN1::GUS and control 35S::GUS lines showed no statistical significant differences in GUS activities upon treatment (Figure 6c). Finally, since StSN1 was proposed as a component of defence barriers against pathogens (Segura et al. 1999) and found to be active against pathogens in vivo (Almasia et al. 2008), analysis of GUS activity was performed after Pseudomonas syringae infection. Intact leaves of the Arabidopsis transgenic lines were inoculated with bacterial suspensions by spraying and plants were collected at $24 \mathrm{hrs}$ and $72 \mathrm{hrs}$ after infection. At $24 \mathrm{hrs}$ post infection, when the scoring of visually disease symptoms was low, GUS activities were equal to those at $72 \mathrm{hrs}$ when plentiful infection symptoms were observed (data not shown). At 72 hrs post-infection GUS activities seemed to be higher than control uninfected plants in two of the PStSN1::GUS lines (Line 2B and 5C) but no statistical significant differences were registered. In addition, for the other two lines (8B and 11A) GUS activities remained 
unchanged or even showed a decrease when compared to uninfected plants (Figure $6 d)$.

In summary, in the conditions tested in this work, PStSN1 was unaltered by hormone treatments, exposure to light/darkness, UV radiation or bacterial infection in statistically significant.

$\mathbf{a}$

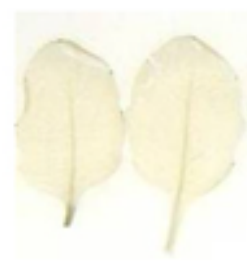

b

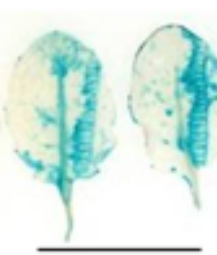

$1 \mathrm{~h}$

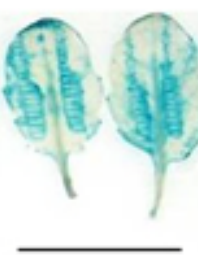

$\mathbf{2 h}$

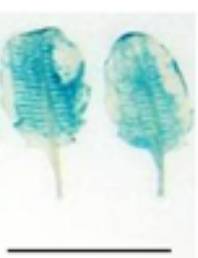

$3 \mathbf{h}$

Wounded

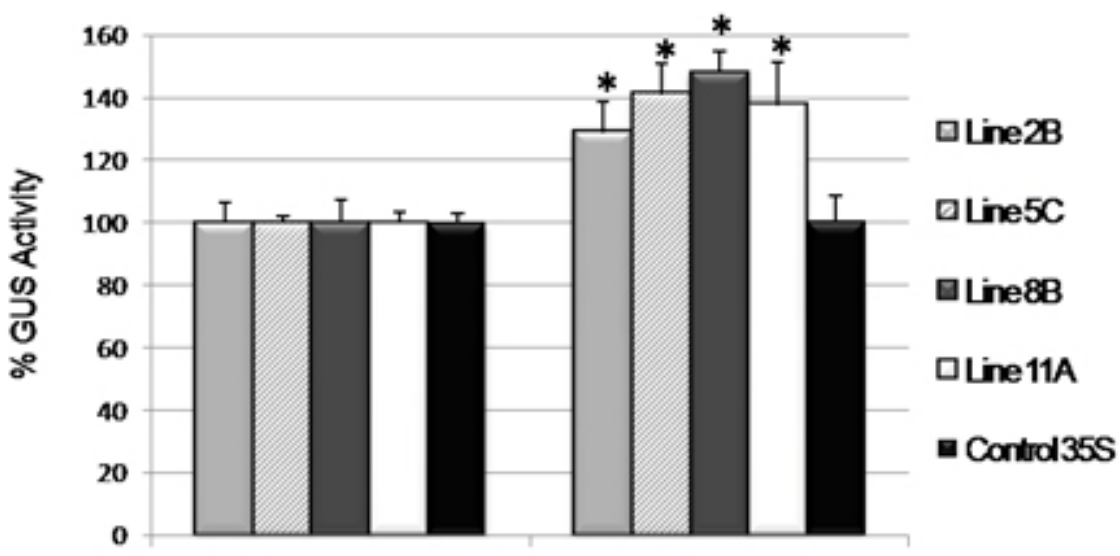

C

Unwounded

Wounded

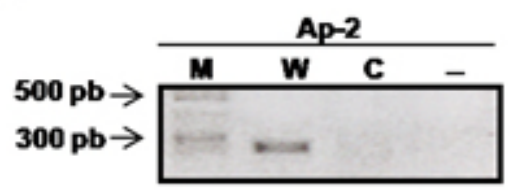

Actin-2

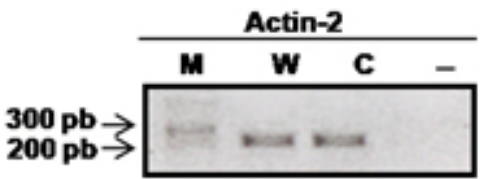

Fig. 5 Wound induction of PStSN1 activity in transgenic Arabidopsis lines. For mechanical wounding treatments, leaves were gently pressed with a pair of sterilized serrated forceps. Four independent transgenic Arabidopsis lines harboring PStSN1::GUS construct (Lines 2B, 5C, 8B and $11 \mathrm{~A}$ ) and one $35 \mathrm{~S}::$ GUS transgenic control line were evaluated. (a) Representative leaves of weak expressing line (Line 11A) were stained at 1,2 or 3 hrs after wounding (note that leaves were pressed one, two or three times, respectively). (b) GUS activity assays of whole plants collected 2 hrs after wounding. Activity of the wounded plants was measured and relatively expressed to the average activity of the unwounded plants of the same line. Bar graphs represent the average percentage of GUS activity \pm SE measured in ten biological replicates.(c) Wound-inducible $A p-2$ gene was amplified by RT-PCR (left panel) to check treatment effectiveness. Specific Actin-2 transcript amplification was detected in all plants as an internal control for cDNA synthesis (right panel). M: Molecular Marker $1 \mathrm{~Kb}$; $(-)$ Negative PCR control (without DNA). * denote significant differences $(P<0.05)$. 


\section{DISCUSSION}

Even though StSN1 was implied in defence against pathogen infections, it belongs to a gene family under active investigation which includes proteins with different roles. Several StSN1 homologous proteins have been involved in many important biological processes, including growth, flowering and seed development (Aubert et al. 1998; Kotilainen et al. 1999; Ben-Nissan et al. 2004; De La Fuente et al. 2006; Furukawa et al. 2006; Roxrud et al. 2007). Because of the importance of the StSN1 broadspectrum antimicrobial activity and the lack of information about the regulation of its expression, an analysis of its promoter activity is highly informative. In this work, we described for the first time the isolation and characterization of a potato promoter of the snakin/GASA cysteine-rich peptide family. Histochemical GUS staining in Arabidopsis transgenic plants showed that PStSN1 displayed a specifically regulated expression mainly in vascular tissues, seedlings, aerial parts and floral organs. These results were in agreement with potato StSN1 gene expression analysis done by RNA gel blot and in situ hybridization experiments (Segura et al. 1999) suggesting that the main potato cis-elements related to tissue-specificity are also recognized in Arabidopsis plants. Although preferential expression in the above mentioned organs is a frequent feature of plant antimicrobial peptides (Segura et al. 1999), a role in defence is not incompatible with other possible functions.

Expression patterns of Arabidopsis homologues are quite diversified (Herzog et al. 1995; Aubert et al. 1998; Raventos et al. 2000; Roxrud et al. 2007; Zhang and Wang, 2008; Zhang et al. 2009). However, none of the described GASA gene expression patterns fully matches with that driven by PStSN1 in this work, suggesting a wider spectrum functionality of this peculiar potato family member. In PStSN1::GUS transgenic plants GUS expression decreased as the plant aged, similarly to the temporal expression pattern reported for pGASA3-driven GUS transgenic Arabidopsis plants (Roxrud et al. 2007). In roots, PStSN1 directed GUS expression was restricted to the vascular cylinder in the zone of elongating cells above the root tip, gradually becoming weaker in the more mature parts of the root tissue (Figure $2 n$ ). GASA 8 and GASA14 from Arabidopsis were proposed to be involved in cell elongation (Roxrud et al. 2007) since theirs promoters were highly active in zones typically associated with cell expansion, such as growing cotyledons and cells above the root initials. In view of the fact that PStSN1 activity is comparable to pGASA8 and pGASA14 expression patterns we also propose StSN1 as a candidate for being involved in similar processes. In addition, since differential GUS staining was observed in the stigma and filaments of young and mature flowers, it suggests that StSN1 might also play a role in flower development. This PStSN1 directed GUS floral pattern is similar to that observed in pGASA14-driven GUS transgenic Arabidopsis plants. Also, strong GUS localization was observed in the flower abscission zone directed by both PStSN1 and pGASA1 promoters (Raventos et al. 2000; Roxrud et al. 2007). Moreover, the PStSN1 directed GUS expression pattern is similar to the one described for pGASA5 which has been recently proposed as a negative regulator of flowering and stem growth (Zhang et al. 2009).

In this work we provide for the first time the description of a snakin/GASA family promoter modulation. Temperature- and wound-induction of PStSN1 was determined by qualitative and quantitative GUS activity assays after plants treatments. Even truncated promoter studies will be necessary to identify the exact region responsible for the specific activity, for functional purpose the demonstrated induction is sufficiently relevant. Induction of this antimicrobial gene promoter upon a temperature 
increase could be due to the fact that plant pathogens can penetrate host tissues by natural apertures such as stomata and plants keep them opened during heat stress to promote cooling by transpiration. In addition, the observed induction of StSN1 expression under low temperatures is not surprising for genes that contribute to pathogen resistance, as it was described for antifungal proteins 1 , 3- $\beta$-glucanases activities (Koretsky, 2001). Further, promoters induced by environmental cues, are usually associated with plant defense and survival (Venter and Botha, 2004). One striking feature of PStSN1 is that wounding could activate reporter gene expression in transgenic Arabidopsis plants but Pseudomonas syringae infection could not. Conversely, the other potato member of this family (StSN2) is locally induced by wounding and also responds to pathogen infection (Berrocal-Lobo et al. 2002). Plant pathogens can penetrate host tissues by a variety of means; one of them is through damaged tissues. Altogether, these observations are congruent with the hypothesis that StSN1 and StSN2 are components of both constitutive and inducible defence barriers, but StSN1 seems to be more important during the first steps of infection (i.e. if an injury occurs) while StSN2 could be important in later steps of pathogen penetration. Additionally, StSN1 might also function as an antioxidant as proposed for Petunia homologous genes (Ben-Nissan et al. 2004; Wigoda et al. 2006) supporting the need for its presence at the first steps of plant pathogens response. Emerging evidence suggests that ROS signalling pathways as well as hormone signalling pathways play key roles in the crosstalk between biotic and abiotic stress signalling (Fujita et al. 2006; Pieterse et al. 2009). In this context, the results obtained in this work for PStSN1 are not surprising and are in accordance with other defence genes promoters that respond to a variety of environmental stresses. For example pepper CaPMEI1 promoter is induced by pathogen infections and by treatment with ethylene and MeJA (An et al. 2009) and maize PR10 gene was reported to be induced by SA, $\mathrm{CuCl}_{2}, \mathrm{H}_{2} \mathrm{O}_{2}$, coldness, darkness, pathogen infections and wounding (Xie et al. 2009).

A straightforward search for transcription factor binding sites represented by consensus sequences or weight matrices leads to the drawback of false positives due to the lack of knowledge and/or computerization of the complete requisites for cisregulatory modules to be functional, as well as not having taken into account the influence of chromatin structure and DNA stability and flexibility, which are important for determining the affinity and accessibility of the binding sites (Wasserman and Sandelin, 2004; Blüthgen et al. 2005). In this work, that seemed to be the case of the putative phytohormone regulation sites and those putatively involved in defence or light responses, at least in our experimental conditions.

The current work provided an insight into the region that control the temporal- and spatial-specific expression and stress responses of the potato StSN1 gene in a model plant establishing a framework for further studies on the identification of regulatory elements in this promoter. Additionally, PStSN1 is a good candidate for foreign genes expression providing a potential tool for plant modification through genetic engineering. Constitutive high-level expression of defence genes is undesirable since it may create major shifts in metabolism in the absence of a environmental stresses (Ralph et al. 2006; Godard et al. 2007). The use of temperature inducible promoter offers the advantage of increase tolerance of crops in extreme temperature giving rise to minimal effects on plant growth. For example, it has been reported freezing tolerance in transgenic potato (Pino et al. 2007) and tobacco (Kasuga et al. 2004) through the use of stress inducible promoter. Moreover, in this last case, inducible promoter provides an even greater tolerance to stress conditions than did expression of the gene under the control of 35S CaMV promoter which resulted in severe growth retardation. In addition, delayed leaf senescence in tobacco plants were achieved 
through expression of an isopentenyl transferase under the control of a heat shock promoter (Smart et al. 1991). On the other hand, wound inducible promoters have been successfully exploited to increase insect bite resistance (Gulbitti-Onarici et al. 2009; Kumar et al. 2009), to increase phytopathogenic fungi infection (Keller et al. 1999; Rizhsky and Mittler, 2001; Corrado et al. 2005) and for engineering virus resistance (Corrado et al. 2008). In conclusion, since the inducible potato PStSN1 could restrict the expression of interest genes to defined tissues and developmental stages it could be relevant for plant biotechnology mainly for the generation of transgenic crops with more favourable public acceptance.
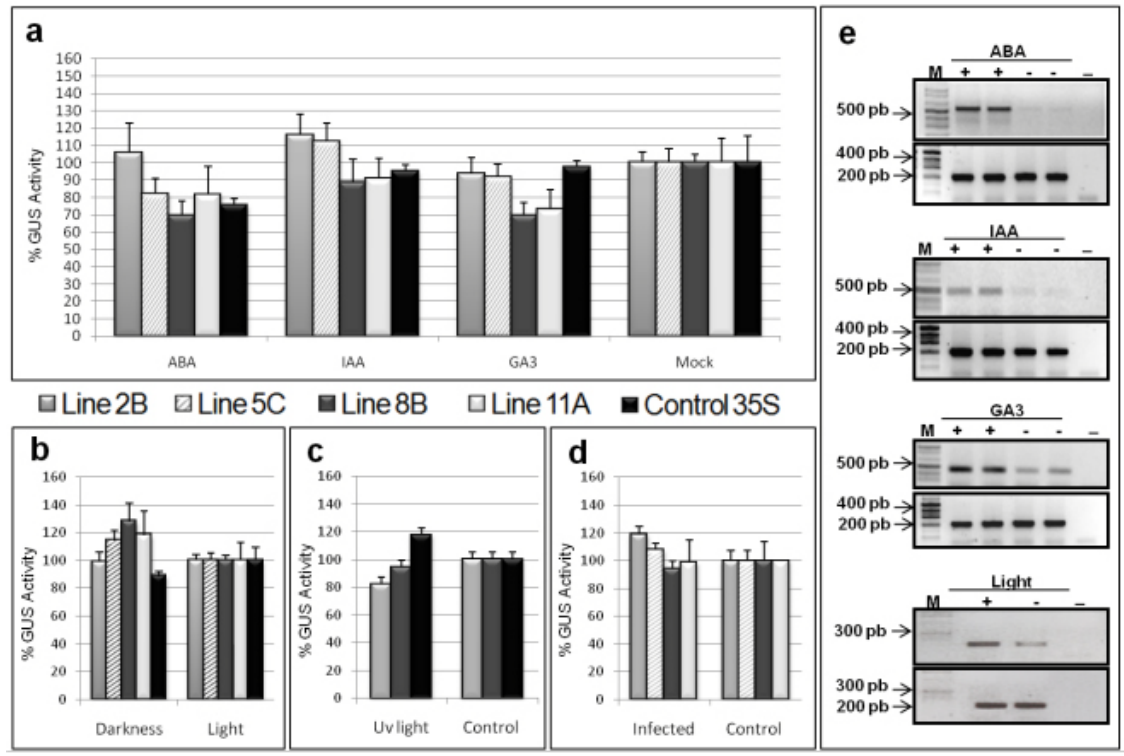

Fig. 6 Constitutive PStSN1 activity Arabidopsis lines after phytohormones, light, UV radiation or Pseudomonas syringae infection. Independent transgenic Arabidopsis lines harboring PStSN1::GUS constructs (Lines 2B, 5C, 8B and 11A) and a 35S::GUS transgenic line were evaluated upon different treatments. GUS activity was measured and percentages were calculated relative to untreated control data. The data represent the average percentage of GUS activity \pm SE measured in eight ( $a$ and $b$ ) or ten biological replicates (d).(a) Phytohormones Treatments. Whole plants were sprayed with abscisic acid (ABA), indol acetic acid (IAA), gibberellic acid, $\left(\mathrm{GA}_{3}\right)$ or mock-treated with water and collected al $6 \mathrm{~h}$ to evaluate GUS activity. (b) Light Treatment. Plants grown under 10 hrs dark-14 hrs light cycle, were covered and kept in darkness or left to continue the normal light cycle for $4 \mathrm{~h}$ prior to collection. (c) UV radiation Treatment. Fifty 14-days-old seedlings of each PStSN1::GUS line were collected 2 hrs after exposure to a UV light bulb and pooled (Errors bars correspond to three techniques replicates). (d) Pseudomonas syringae infection. Pathogen Pseudomonas syringae suspensions (Infected) or $10 \mathrm{mM} \mathrm{MgSO}_{4}$ (Control) were sprayed on intact leaves and whole plants were collected at 72 hrs post infection. (e) Treatment effectiveness was assayed by RT-PCR of different inducible genes: ABA-inducible RD22 (NM_122472); IAA-inducible SAURAC1 (S70188), GA ${ }_{3}$-inducible APT1 (NM_179383) and light-inducible CHS gene (NM_121396). Specific Actin-2 (NM_112764) transcript amplification was detected in all plants as an internal control of cDNA synthesis (lower panel of each treatment). M: Molecular Marker $1 \mathrm{~Kb}$; (-) Negative PCR control (without DNA). 


\section{ACKNOWLEDGMENTS}

Dr. Asurmendi (IB-INTA) kindly facilitated the plasmids EV::GUS and 35S::GUS. Infection treatments were carried out in collaboration with Matías Rugnone from Dr. Marcelo Yanovsky's laboratory (IFEVA-CONICET). We thank Valeria Beracochea (IBINTA) for expert technical assistance. We also thank Diego Zavallo (IB-INTA) and Teresa Cabrera (IB-INTA) for their helpful assistance. We acknowledge Mariana del Vas, Guillermo Maroniche and Vanesa Mongelli for critically reading this manuscript and helpful discussions. NIA holds a CONICET/INTA fellowship; VN holds a CONICET fellowship. CVR is a career member of CONICET and HEH of CIC (Comisión de Investigaciones Científicas de la Provincia de Buenos Aires).

Financial support: This research was supported by grants UBACyT X-101 (University of Buenos Aires-UBA), PE AEBIO4461 (INTA).

\section{REFERENCES}

ALMASIA, Natalia I.; BAZZINI, Ariel A.; HOPP, H. Esteban and VAZQUEZ-ROVERE, Cecilia. Overexpression of snakin-1 gene enhances resistance to Rhizoctonia solani and Erwinia carotovora in transgenic potato plants. Molecular Plant Pathology, May 2008, vol. 9, no. 3, p. 329-338. [CrossRef]

AN, Soo Hyun; CHOI, Hyong Woo; HONG, Jeum Kyu and HWANG, Byung Kook. Regulation and function of the pepper pectin methylesterase inhibitor (CaPMEI1) gene promoter in defense and ethylene and methyl jasmonate signaling in plants. Planta, November 2009, vol. 230 , no. 6 , p. 1223-1237. [CrossRef]

AUBERT, Dominique; CHEVILLARD, Martine; DORNE, Anne-Marie; ARLAUD, Gerard and HERZOG, Michel. Expression patterns of GASA genes in Arabidopsis thaliana: the GASA4 gene is up-regulated by gibberellins in meristematic regions. Plant Molecular Biology, April 1998, vol. 36, no. 6, p. 871-883. [CrossRef]

BAZZINI, Ariel A.; ALMASIA, Natalia I.; MANACORDA, Carlos A.; MONGELLI, Vanesa C.; CONTI, Gabriela; MARONICHE, Guillermo A.; RODRIGUEZ, Maria C.; DISTÉFANO, Ana J.; HOPP, H. Esteban; DEL VAS, Mariana and ASURMENDI, Sebastian. Virus infection elevates transcriptional activity of miR164a promoter in plants. BMC Plant Biology, December 2009, vol. 9, no. 9, p. 152. [CrossRef]

BEN-NISSAN, Gili and WEISS, David. The petunia homologue of tomato gast1: transcript accumulation coincides with gibberellin-induced corolla cell elongation. Plant Molecular Biology, December 1996, vol. 32, no. 6, p. 1067-1074. [CrossRef]

BEN-NISSAN, Gili; LEE, Jung Youn; BOROHOV, Amihud and WEISS, David. GIP, a Petunia hybrida GA-induced cysteine-rich protein: a possible role in shoot elongation and transition to flowering. The Plant Journal, January 2004, vol. 37, no. 2, p. 229-238.

BERROCAL-LOBO, Marta; SEGURA, Ana; MORENO, Manuel; LOPEZ, Gemma; GARCIAOLMEDO, Francisco and MOLINA, Antonio. Snakin-2, an antimicrobial peptide from potato whose gene is locally induced by wounding and responds to pathogen infection. Plant Physiology, March 2002, vol. 128, no. 3, p. 951-961. [CrossRef]

BLÜTHGEN, Nils; KIELBASA, Szymon M. and HERZEL, Hanspeter. Inferring combinatorial regulation of transcription in silico. Nucleic Acids Research, January 2005, vol. 33, no. 1, p. 272-279. [CrossRef]

BOYES, Douglas C.; ZAYED, Adel M.; ASCENZI, Robert; McCASKILL, Amy J.; HOFFMAN, Neil E.; DAVIS, Keith R. and GÖRLACH, Jörn. Growth stage-based phenotypic analysis of Arabidopsis: a model for high throughput functional genomics in plants. The Plant Cell, July 2001, vol. 13, no. 7, p. 1499-1510. [CrossRef

BRADFORD, Marion $M$. A rapid and sensitive method for the quantitation of microgram quantities of protein utilizing the principle of protein-dye binding. Analytical Biochemistry, May 1976, vol. 72, no. 1-2, p. 248-254. [CrossRef] 
BRADY, Siobhan M.; ORLANDO, David A.; LEE, Ji Young; WANG, Jean Y.; KOCH, Jeremy; DINNENY, Jose R.; MACE, Daniel; OHLER, Uwe and BENFEY, Philip N. A highresolution root spatiotemporal map reveals dominant expression patterns. Science, November 2007, vol. 318, no. 5851, p. 801-806. [CrossRef]

CHARNG, Yee-Yung; LIU, Hsiang-Chin; LIU, Nay-Yu; CHI, Wen Tzu; WANG, Chun-Neng; CHANG, Shih-Hsun and WANG, Tsu-Tsuen. A heat-inducible transcription factor, HsfA2, is required for extension of acquired thermotolerance in Arabidopsis. Plant Physiology, January 2007 , vol. 143 , no. 1, p. 251-262. [CrossRef]

CLOUGH, Steven J. and BENT, Andrew F. Floral dip: a simplified method for Agrobacteriummediated transformation of Arabidopsis thaliana. The Plant Journal, December 1998, vol. 16, no. 6, p. 735-743. [CrossRef]

CORRADO, Giandomenico; BOVI, Pasqualle Delli; CILIENTO, Rosalia; GAUDIO, Luciano; DI MARO, Antimo; ACETO, Serena; LORITO, Matteo and RAO, Rosa. Inducible expression of a Phytolacca heterotepala ribosome-inactivating protein leads to enhanced resistance against major fungal pathogens in tobacco. Phytopathology, February 2005, vol. 95, no. 2, p. 206-215. [CrossRef]

CORRADO, Giandomenico; SCARPETTA, Mariarosaria; ALIOTO, Daniela; DI MARO, Antimo; POLITO, Letizia; PARENTE, Augusto and RAO, Rosa. Inducible antiviral activity and rapid production of the Ribosome-Inactivating Protein I from Phytolacca heterotepala in tobacco. Plant Science, April 2008, vol. 174, no. 4, p. 467-474. [CrossRef]

DE LA FUENTE, José I.; AMAYA, Iraida; CASTILLEJO, Cristina; SANCHEZ-SEVILLA, Jose F.; QUESADA, Miguel A.; BOTELLA, Miguel A. and VALPUESTA, Victoriano. The strawberry gene FaGAST affects plant growth through inhibition of cell elongation. Journal of Experimental Botany, June 2006, vol. 57, no. 10, p. 2401-2411. [CrossRef]

DE TORRES, Marta; SANCHEZ, Pedro; FERNANDEZ-DELMOND, Isabelle and GRANT, Murray. Expression profiling of the host response to bacterial infection: the transition from basal to induced defence responses in RPM1-mediated resistance. The Plant Journal, February 2003, vol. 33, no. 4, p. 665-676. [CrossRef]

DE TORRES, Marta; MANSFIELD, John W.; GRABOV, Nina; BROWN, Ian R.; AMMOUNEH Hassan; TSIAMIS, George; FORSYTH, Alec; ROBATZEK, Silke; GRANT, Murray and $\mathrm{BOCH}$, Jens. Pseudomonas syringae effector AvrPtoB suppresses basal defence in Arabidopsis. The Plant Journal, August 2006, vol. 47, no. 3, p. 368-382. [CrossRef]

DELESSERT, Christian; KAZAN, Kemal; WILSON, lain W.; VAN DER STRAETEN, Dominique; MANNERS, John; DENNIS, Elizabeth S. and DOLFERUS, Rudy. The transcription factor ATAF2 represses the expression of pathogenesis-related genes in Arabidopsis. The Plant Journal, September 2005, vol. 43, no. 5, p. 745-757. [CrossRef]

FEINBAUM, R.L. and AUSUBEL, F.M. Transcriptional regulation of the Arabidopsis thaliana chalcone synthase gene. Molecular and Cellular Biology, May 1988, vol. 8, no. 5, p. 19851992.

FUJITA, Miki; FUJITA, Yasunari; NOUTOSHI, Yoshiteru; TAKAHASHI, Fuminori; NARUSAKA, Yoshihiro; YAMAGUCHI-SHINOZAKI, Kazuko and SHINOZAKI, Kazuo. Crosstalk between abiotic and biotic stress responses: a current view from the points of convergence in the stress signaling networks. Current Opinion in Plant Biology, August 2006, vol. 9, no. 4, p. 436-442. [CrossRef]

FURUKAWA, Tomoyuki; SAKAGUCHI, Norihiro and SHIMADA, Hiroaki. Two OsGASR genes, rice GAST homologue genes that are abundant in proliferating tissues, show different expression patterns in developing panicles. Genes and Genetic System, June 2006, vol. 81, no. 3, p. 171-180. [CrossRef]

GIL, P.; LIU, Y.; ORBOVIC, V.; VERKAMP, E.; POFF, K.L. and GREEN, P.J. Characterization of the auxin-inducible SAUR-AC1 gene for use as a molecular genetic tool in Arabidopsis. Plant Physiology, February 1994, vol. 104, no. 2, p. 777-784. [CrossRef]

GITTINS, John R.; PELLNY, Till K.; HILES, Elizabeth R.; ROSA, Cristina; BIRICOLTI, Stefano and JAMES, David J. Transgene expression driven by heterologous ribulose-1,5bisphosphate carboxylase/oxygenase small-subunit gene promoters in the vegetative tissues of apple (Malus pumila mill.). Planta, January 2000, vol. 210, no. 2, p. 232-240. [CrossRef]

GODARD, Kimberley-Ann; BYUN-MCKAY, Ashley; LEVASSEUR, Caroline; PLANT, Aine; SEGUIN, Armand and BOHLMANN, Jörg. Testing of a heterologous, wound- and insectinducible promoter for functional genomics studies in conifer defense. Plant Cell Reports, December 2007, vol. 26, no. 12, p. 2083-2090. [CrossRef] 
GULBITTI-ONARICI, Selma; ZAIDI, Mohsin Abbas; TAGA, Ibrahim; OZCAN, Sebahattin and ALTOSAAR, Illimar. Expression of Cry1Ac in transgenic tobacco plants under the control of a wound-inducible promoter (AoPR1) isolated from Asparagus officinalis to control Heliothis virescens and Manduca sexta. Molecular Biotechnology, July 2009, vol. 42, no. 3, p. 341-349. [CrossRef]

HAYASHI, Ken-Ichiro; JONES, Alan M.; OGINO, Kentaro; YAMAZOE, Atsushi; OONO, Yutaka; INOGUCHI, Masahiko; KONDO, Hirokiyo and NOZAKI, Hiroshi. Yokonolide B, a novel inhibitor of auxin action, blocks degradation of AUX/IAA factors. The Journal Biological Chemistry, June 2003, vol. 278, no. 26, p. 23797-23806. [CrossRef]

HERZOG, Michel; DORNE, Anne-Marie and GRELLET, Françoise. GASA, a gibberellinregulated gene family from Arabidopsis thaliana related to the tomato GAST1 gene. Plant Molecular Biology, February 1995, vol. 27, no. 4, p. 743-752. [CrossRef]

HIGO, Kenichi; UGAWA, Yoshihiro; IWAMOTO, Masao and KORENAGA, Tomoko. Plant cisacting regulatory DNA elements (PLACE) database: 1999. Nucleic Acids Research, January 1999, vol. 27, no. 1, p. 297-300. [CrossRef

IACOBELLIS, Nicola Sante; COLLMER, Alan; HUTCHESON, Steven W.; MANSFIELD, John W.; MORRIS, Cindy E.; MURILLO, Jesus; SCHAAD, Norman W.; STEAD, David E.; SURICO, Giuseppe and ULLRICH, Matthias S. Pseudomonas syringae and related pathogens: biology and genetics. Dordrecht, The Nethaerlands, Kluwer Academic Pub. Group. 2003, 688 p. ISBN 1-4020-1227-6.

JEFFERSON, R.A.; BEVAN, M. and KAVANAGH, T. The use of the Escherichia coli betaglucuronidase as a gene fusion marker for studies of gene expression in higher plants. Biochemical Society Transaction, February 1987, vol. 15, no. 1, p. 17-18.

KASUGA, Mie; MIURA, Setsuko; SHINOZAKI, Kazuo and YAMAGUCHI-SHINOZAKI, Kazuko. A combination of the Arabidopsis DREB1A gene and stress-inducible rd29A promoter improved drought- and low temperature stress tolerance in tobacco by gene transfer. Plant and Cell Physiology, March 2004, vol. 45, no. 3, p. 346-350. [CrossRef]

KATIYAR-AGARWAL, Surekha; AGARWAL, Manu and GROVER, Anil. Emerging trends in agricultural biotechnology research: Use of abiotic stress-induced promoter to drive expression of a stress resistance gene in the transgenic system leads to high level stress tolerance associated with minimal negative effects on growth. Current Science Online, December 1999, vol. 77 no. 12.

KELLER, Harald; PAMBOUKDJIAN, Nicole; PONCHET, Michel; POUPET, Alain; DELON, Réne; VERRIER, Jean-Louis; ROBY, Dominique and RICCI, Pierre. Pathogen-induced elicitin production in transgenic tobacco generates a hypersensitive response and nonspecific disease resistance. The Plant Cell, February 1999, vol. 11, no. 2, p. 223-236. [CrossRef]

KORETSKY, Liuba S. The influence of Fusarium oxysporum infection and low temperatures on the activity of soybean esterase and PR proteins. Búvisindi, Icelandic. Agricultural. Science, 2001, vol. 14, p. 67-73.

KOTILAINEN, Mika; HELARIUTTA, Yrjö; MEHTO, Merja; PÖLLÄNEN, Elija; ALBERT, Victor A.; ELOMAA, Paula and TEERI, Teemu H. GEG participates in the regulation of cell and organ shape during corolla and carpel development in Gerbera hybrida. The Plant Cell, June 1999, vol. 11, no. 6, p. 1093-1104. [CrossRef]

KUMAR, Manoj; SHUKLA, Anoop Kumar; SINGH, Harpal and TULI, Rakesh. Development of insect resistant transgenic cotton lines expressing cry1EC gene from an insect bite and wound inducible promoter. Journal of Biotechnology, March 2009, vol. 140, no. 3-4, p. 143-148. [CrossRef]

LESCOT, Magali; DEHAIS, Patrice; THIJS, Gert; MARCHAL, Kathleen; MOREAU, Yves; VAN DE PEER, Yves; ROUZE, Pierre and ROMBAUTS, Stephane. PlantCARE, a database of plant cis-acting regulatory elements and a portal to tools for in silico analysis of promoter sequences. Nucleic Acids Research, January 2002, vol. 30, no. 1, p. 325-327. [CrossRef]

MOFFATT, Barbara A.; MCWHINNIE, Elizabeth A.; AGARWAL, Sunita K. and SCHAFF, Dennis A. The adenine phosphoribosyltransferase-encoding gene of Arabidopsis thaliana. Gene, June 1994, vol. 143, no. 2, p. 211-216. [CrossRef]

OCHMAN, Howard; GERBER, Anne S. and HARTL, Daniel L. Genetic applications of an inverse polymerase chain reaction. Genetics, November 1988, vol. 120, no. 3, p. 621-623.

OSTERYOUNG, Katherine W.; SUNDBERG, Holly and VIERLING, Elizabeth. Poly(A) tail length of a heat shock protein RNA is increased by severe heat stress, but intron splicing is unaffected. Molecular and General Genetics MGG, Jun 1993, vol. 239, no. 3, p. 323-333. [CrossRef] 
PIETERSE, Corné M.J.; LEON-REYES, Antonio; VAN DER ENT, Sjoerd and VAN WEES, Saskia C.M. Networking by small-molecule hormones in plant immunity. Nature Chemical Biology, May 2009, vol. 5, no. 5, p. 308-316. [CrossRef]

PINO, Maria Teresa; SKINNER, Jeffrey S.; PARK, Eung Jun; JEKNIC, Zoran; HAYES, Patrick M.; THOMASHOW, Michael F. and CHEN, Tony H.H. Use of a stress inducible promoter to drive ectopic AtCBF expression improves potato freezing tolerance while minimizing negative effects on tuber yield. Plant Biotechnology Journal, September 2007, vol. 5, p. 591-604. [CrossRef]

RALPH, Steven; PARK, Ji-Young; BOHLMANN, Jörg and MANSFIELD, Shawn D. Dirigent proteins in conifer defense: Gene discovery, phylogeny, and differential wound- and insect-induced expression of a family of DIR and DIR-like genes in spruce (Picea spp.). Plant Molecular Biology, January 2006, vol. 60, no. 1, p. 21-40. [CrossRef

RAVENTOS, Dora; MEIER, Carsten; MATTSSON, Ole; JENSEN, Anders B. and MUNDY, John. Fusion genetic analysis of gibberellin signaling mutants. The Plant Journal, June 2000, vol. 22, no. 5, p. 427-438. [CrossRef]

RIECHMANN, J.L.; HEARD, J.; MARTIN, G.; REUBER, L.; JIANG, C.; KEDDIE, J.; ADAM, L.; PINEDA, O.; RATCLIFFE, O.J.; SAMAHA, R.R.; CREELMAN, R.; PILGRIM, M.; BROUN, P.; ZHANG, J.Z.; GHANDEHARI, D.; SHERMAN, B.K. and YU, G. Arabidopsis transcription factors: Genome-wide comparative analysis among eukaryotes. Science, December 2000, vol. 290, no. 5499, p. 2105-2110. [CrossRef]

RIZHSKY, Ludmila and MITTLER, Ron. Inducible expression of bacterio-opsin in transgenic tobacco and tomato plants. Plant Molecular Biology, June 2001, vol. 46, no. 3, p. 313-323. [CrossRef]

ROMBAUTS, Stephane; DÉHAIS, Patrice; VAN MONTAGU, Marc and ROUZÉ, Pierre. PlantCARE, a plant cis-acting regulatory element database. Nucleic Acids Research, January 1999, vol. 27, no. 1, p. 295-296. [CrossRef]

ROXRUD, Ingrid; LID, Stein Erik; FLETCHER, Jennifer C.; SCHMIDT, Ed D.L. and OPSAHLSORTEBERG, Hilde-Gunn. GASA4, one of the 14-member Arabidopsis GASA family of small polypeptides, regulates flowering and seed development. Plant and Cell Physiology, March 2007, vol. 48, no. 3, p. 471-483. [CrossRef]

SAMBROOK, J.; FRITSCH, E. and MANIATIS, T. Molecular cloning, A laboratory Manual. 2nd Edition, Cold Spring Harbor Laboratory Press. 1989. 1659 p. ISBN 0-87969-309-6.

SEGURA, Ana; MORENO, Manuel; MADUEÑO, Francisco; MOLINA, Antonio and GARCIAOLMEDO, Francisco. Snakin-1, a peptide from potato that is active against plant pathogens. Molecular Plant-Microbe Interactions, January 1999, vol. 12, no. 1, p. 16-23. [CrossRef

SHI, Lifang; GAST, Robert T.; GOPALRAJ, Manjula and OLSZEWSKI, Neil E. Characterization of a shoot-specific, $\mathrm{GA}_{3}$ - and ABA-regulated gene from tomato. The Plant Journal, March 1992, vol. 2, no. 2, p. 153-159. [CrossRef]

SMART, Catherine M.; SCOFIELD, Steven R.; BEVAN, Michael W. and DYER, Tristan A. Delayed leaf senescence in tobacco plants transformed with tmr, a gene for cytokinin production in Agrobacterium. The Plant Cell, July 1991, vol. 3, no. 7, p. 647-656. [CrossRef]

TAYLOR, Brian H. and SCHEURING, Chantel F. A molecular marker for lateral root initiation: the RSI-1 gene of tomato (Lycopersicon esculentum Mill) is activated in early lateral root primordia. Molecular and General Genetics, March 1994, vol. 243, no. 2, p. 148-157.

VENTER, Mauritz and BOTHA, Frederik C. Promoter analysis and transcription profiling: Integration of genetic data enhances understanding of gene expression. Physiologia Plantarum, January 2004, vol. 120, no. 1, p. 74-83. [CrossRef]

WASSERMAN, Wyeth W. and SANDELIN, Albin. Applied bioinformatics for the identification of regulatory elements. Nature Reviews Genetics, April 2004, vol. 5, no. 4, p. 276-287. [CrossRef]

WIGODA, Noa; BEN-NISSAN, Gili; GRANOT, David; SCHWARTZ, Amnon and WEISS, David. The gibberellin-induced, cysteine-rich protein GIP2 from Petunia hybrida exhibits in planta antioxidant activity. The Plant Journal, December 2006, vol. 48, no. 5, p. 796-805. [CrossRef]

XIE, Yu-rong; CHEN, Zhi-Yuan; BROWN, Robert L. and BHATNAGAR, Deepak. Expression and functional characterization of two pathogenesis-related protein 10 genes from Zea mays. Journal of Plant Physiology, January 2010, vol. 167, no. 2, p. 121-130. [CrossRef] 
YAMAGUCHI-SHINOZAKI, Kazuko and SHINOZAKI, Kazuo. Arabidopsis DNA encoding two desiccation-responsive rd29 genes. Plant Physiology, March 1993a, vol. 101, no. 3, p. 1119-1120. [CrossRef]

YAMAGUCHI-SHINOZAKI, Kazuko and SHINOZAKI, Kazuo. The plant hormone abscisic acid mediates the drought-induced expression but not the seed-specific expression of $r d 22$, a gene responsive to dehydration stress in Arabidopsis thaliana. Molecular and General Genetics MGG, April 1993b, vol. 238, no. 1-2, p. 17-25.

YAMAMOTO, Yoshiharu Y.; ICHIDA, Hiroyuki; MATSUI, Minami; OBOKATA, Junichi; SAKURAI, Tetsuya; SATOU, Masakazu; SEKI, Motoaki; SHINOZAKI, Kazuo and ABE, Tomoko. Identification of plant promoter constituents by analysis of local distribution of short sequences. BMC Genomics, March 2007, vol. 8, no. 67. [CrossRef]

ZHANG, Shengchun. and WANG, Xiaojing. Expression pattern of GASA, downstream genes of DELLA, in Arabidopsis. Chinese Science Bulletin, December 2008, vol. 53, no. 24, p. 3839-3846. [CrossRef]

ZHANG, Shengchun; YANG, Chengwei; PENG, Jianzong; SUN, Shulan and WANG, Xiaojing. GASA5, a regulator of flowering time and stem growth in Arabidopsis thaliana. Plant Molecular Biology, April 2009, vol. 69, no. 6, p. 745-759. [CrossRef]

\section{How to cite this article:}

ALMASIA, N.I.; NARHIRÑAK, V.; HOPP, H.E. and VAZQUEZ-ROVERE, C. Isolation and characterization of the tissue and development-specific potato snakin-1 promoter inducible by temperature and wounding. Electronic Journal of Biotechnology, September 2010, vol. 13, no. 5. http://dx.doi.org/10.2225/vol13-issue5fulltext-12 